\title{
Writing from a Distance. The Past and the Present in Novels by Central and Eastern European Female Migrant Writers in Italy
}

Abstract: Belozorovich Anna, Writing from a Distance. The Past and the Present in Novels by Central and Eastern European Female Migrant Writers in Italy. "Poznańskie Studia Slawistyczne" 17. Poznań 2019. Publishing House of the Poznań Society for the Advancement of the Arts and Sciences, Adam Mickiewicz University, pp. 23-41. ISSN 2084-3011.

Based on a research concerning literary works by the authors from Central and Eastern European countries living in Italy, this article explores the imaginary bonded to a vast geographical area and to a variety of social experiences connected to that area under regime or to the post-migration condition. The interviews conducted with the selected writers allow the authoress to gather elements that show the perception of the place of origin and its connection with neighboring countries, suggested by different motivations. The literary works cited in the article give testimony of lives under regimes and describe moments of transition due to political and social change or to the choice to migrate. While revealing sometimes a stereotyped view of the idea of 'East' in opposition to the 'West', these different voices, located at a spatial and temporal distance from the social realities they explore, suggest an important role of literary expression as means for contrasting the oblivion of the past and present injustices.

KEYwords: Central and Eastern Europe; migrant literature; Italophone literature; female writing

\section{The other Europe}

This article is based on a broader research, concerning the literary production of the authors from Central and Eastern European countries. The research was also carried out through the collection of interviews with the authors, conducted between 2013 and 2014, some of which will be cited here. The analysis of these interviews and literary works, written in Italian and published in Italy, revealed the presence of an imaginary linked to a geographical area and a shared past, even in the presence of strong 
historical variables. The different narratives have highlighted perceptions of 'before' and 'after', of 'here' and 'there', recognizing, perhaps, precisely in the literary expression an essential tool to point out the peculiarities of power relations, to reflect on the power of language and the use of language by power, in order to propose alternative or complementary representations to the historical or political ones.

A critical starting point is the question of where to locate and how to define the region of interest: The idea of 'Eastern Europe', born during the Enlightenment (Wolff, 1994), enriched with new meanings during the Cold War and finally associated with the 'Soviet Bloc', reveals some fragility since we often do not want to consider its territories in the context of the Russian sphere of influence. 'Mitteleuropa', on the other hand, shows itself more oriented towards Germanic cultures and represents the German perspective not only on countries in the East but also on parts of Germany itself (Neubauer, 2003, 6). 'Central Europe', re-emerged in the 1980s thanks above all to such intellectuals like Czesław Miłosz, Milan Kundera, and Danilo Kiš (Kiš, 1987; Miłosz, 1986; Górska, 2011), would seem to guarantee a certain independence both from Western traditions and Russian influence, attributing to the region a personality of its own (Cornis-Pope, Neubauer, 2002, 9). While the idea of Central Europe had as its purpose precisely that of excluding and differentiating the Balkans, the concept of Central and Eastern Europe, which I use in this article to refer to this large region, appears more comprehensive, applying also to the countries of the ex-Yugoslavia and Albania (Neubauer, 2003, 8-9). The term became crucial after 1989 , following the transformations that led to the end of the socialist regimes, and gained more importance since 2004, when the process of annexation to the European Union of some states of the former Soviet Bloc began (Kłoczowski, 2009, 11-12). While choosing a definition, in this context, is never neutral (Cornis-Pope, Neubauer, 2002,3), it is important to stress that, though using different terminologies, justifications and borders, the other Europe has been at the center of attention of scientists from various fields and has been present for a long time in the collective imagination of the Europeans.

Recalling a geological fault, Central and Eastern Europe has been a manifestation of the 'clash of civilizations' (Huntington, 1993, 29-30), and, just like a collision between tectonic plates, its meaning has changed 
over time but not its position (Kirshenko, 2001). In its most ancient form, the fault divided Europe and Byzantium (Szücs, 1996, 8-9). Later, it defined areas whose populations belonged to different religions (Huntington, 1993, 30-31). The 'middle lands' condition of Central and Eastern European countries became particularly evident between the 1930s and 1940s, when pressures deriving from forces involved in the Second World War produced alliances that had consequences on the political balance of the following decades (Stokes, 1997, 7, 19, 21-22). But even after the end of the Cold War the fault remained, marking a cultural division instead of the ideological one. In more recent times, Central and Eastern European countries have experienced less democratic political systems and have often been the scene of intense, often violent, political and social transformations (Huntington, 1993, 29-31).

Although this synthesis may appear satisfactory at first glance, it is important to emphasize that, just as the 'West' cannot be viewed as a monolith (Todorova, 1996, 9), the region we are taking into consideration contains many categories, such as its Slavic and Orthodox elements, which are not internally homogeneous (Garzaniti, 2013; Graciotti, 1992; 19981999; 2006; Moracci, 2013; Picchio, 1991; Vitale, 2001). Thus, while we observe a co-presence of possible internal lines of separation, which simultaneously involve linguistic and cultural areas both within them and in opposition to what surrounds them, Central and Eastern Europe, with its long history of clashes and overlaps (Brubaker, 1998, 120), can be viewed as a territory of conflict as well as of union (Marinelli, 2008, 73).

In recent times, Central and Eastern European countries have experienced forms of affiliation different either from the religious factor or from the cultural/linguistic one (Ziffer, 2007, 42-49). In this process, "writers have played a primary role", placing themselves on a trajectory that had already seen the emergence of important voices at the international level to the extent that they had manifested forms of dissent and resistance against the regimes under which they lived (Garzaniti, 2013, 35). When Édouard Glissant states that "at the rise of communities there is always an irresistible, poetic cry" (Glissant, 1998, 28), he refers to the communities that have been constituted for millennia, to 'great peoples' that recognize their common origins in 'great books'. Yet the paths of institutionalization of literature in situations of political and identity uncertainty such as those described above follow 
similar paths (Cornis-Pope, Neubauer, 2002, 13). The literary projects born in that context contained all the tension coming from the antagonistic forces that generated them: the intent to establish a central power on the one hand and the voices of minority groups in search of an expression of their own on the other (Neubauer, 2003, 4). For many intellectuals, this other Europe brings into existence an utopian world, "a poetic homeland of extendable topography, where authors consciously set their works" (Bodrožić, 2001; Neubauer, 2003, 2). And so, perhaps, today's authors, even and especially those located at a distance, continue to reflect on the experience that, for them, still identifies an universe positioned along the 'twentieth meridian' (Kąkolewski, Olendzki, 1993).

\section{Moving 'a millimeter'}

The effort itself of defining a common region of provenance while studying migrant literature may be questionable, since connecting the authors to their place of origin seems to express the choice to distance the very same authors from the literary environment where their works are born and published, suggesting, ultimately, that they must be considered 'other' regardless of the quality and the impact of their presence in the cultural field. The question becomes even stronger when we cannot hold to a clearly defined concept such as a country political borders or a common mother-tongue. Still, some data regarding the production of the authors from Central and Eastern European countries in Italy show peculiarities that justify the interest for such selection. For instance, a brief comparison of statistical data regarding migrant population with the frequency of literary publications of any genre has already showed that the percentage of migrants from Central and Eastern European countries in Italy that write and publish in Italian language is high, but especially this number is represented by women in a greater percentage than that the same population presence is on Italian territory (Belozorovich, 2019, 15). Another interesting issue is the one regarding qualitative aspects of such publications and their luck on the Italian market, where works by female writers from Central and Eastern European countries have had the possibility of reaching major editors and are frequently presented with special attention to their 
ability to testimony experiences connected with the region of provenance and its recent history (Belozorovich, 2019, 233-287). Therefore, I would like to suggest that to the theoretical definition of the 'twentieth meridian' area we might add the factual existence, in this specific context, of a category recognized by the literary market and by the public opinion through definitions which are not always so rigorous and seem remain in constant dialogue with the persons they involve, negotiating a 'mission' for their literary production and their position in the cultural field.

That is why a key point of the interviews carried out with the authors was the perception of one's own area of origin and the possibility of connecting it to a larger region that included neighboring countries. Although the question was never explicit (Belozorovich, 2019, 11-12) and used as starting point for literary works, many authors focused one way or another on the description of how they perceived their own place of origin, offering a distinction between the latter and the current location. Associating herself with a wider notion of "Eastern World", the Bosnian Enisa Bukvić speaks of affinities originated from similar readings. The authoress also focuses on the education and on the widespread reading culture in the socialist countries, an aspect also recalled by Anilda Ibrahimi, from Albania: "As a child I read, I read everything”, she says, and this is what „distinguishes everyone from the countries, let's say, beyond the Berlin wall'.

Besides these general references to some common practices and the feeling of a community based on a similar value given to literature and reading in general, the image of "a poetic homeland of extendable topography" (Bodrožić, 2001, 56) might be connected with the choice of setting the novels in a country different from one's own and in the explanation given for such choices by the authors. Duška Kovačević, born in Croatia, places the characters of her novel L'orecchino di Zora ([Zora's earring] 2007) in Bosnia. She explains that this choice was based on the fact that the characters are migrants; still, "it could very well be set in Croatia as well as any other country where people move from to a better world", she says, ,anywhere in Eastern Europe”. The Romanian-born author Irina Țurcanu sets the novel La frivolezza del cristallo liquido ([The frivolity of liquid crystal] 2010) in Chișinău. While admitting that she has never been to Moldova, she explains that this was an attempt not to speak directly of Romania but moving only "a millimeter". Perhaps unconsciously, she 
reflects, "I didn't want to leave Romania, and I didn't want to stay there". Ultimately, "the choice was certainly [between] Italy and non-Italy". In both cases, as well as in several others (ex.: Mujčić, 2012) placing the main character, with whom the authoress shares at least some experiences (being a woman, having migrated), in a different Central European country, a slight shift might be only observed which does not impact on the possibility of developing a credible plot. It must be stressed that the cultural and political environment of the country where the stories are set, is anything but peripheral in these plots, being often described as the cause of the events.

Besides the interviews, some definitions of a broad perception of the region, based on common experiences, are found in the texts. In La mano che non mordi ([The hand that you won't bite] 2007), the Albanian Ornela Vorpsi refers to Central and Eastern European states as to "suffering countries" whose literature "fails to affect as much as it should" (Vorpsi, 2007, 5). In E se Fuad avesse avuto la dinamie? ([What if Fuad had had the dynamite?] 2009), by Serbian-born Elvira Mujčić, the protagonist affirms bitterly "What do they care about the others? It's not their fault if I was born in a problematic country, it's my own business" (Mujčić, 2009, 20), taking into account the Italians / Westerners who cannot understand her anxiety, connected with a hard relationship between the past and the present. Still in Mujčić, in the novel La lingua di Ana ([Ana's language] 2012), the protagonist, a Moldavian teenager, confides: "I was ashamed of coming from a poor country, of being called "the Eastern girl"” (Mujčić, 2012, 64).

These few notes aim to highlight different configurations of possible memberships and share a common lexicon that apparently belongs to all actors in the field, with all its inaccuracies and approximations. A sense of 'us' and 'them' seems to be the most generic and at the same time characterizes symptom of that fracture that lies along the twentieth meridian, maintaining its problematic foundation despite the historical and social changes. The Berlin Wall has fallen, many of the countries of origin of these authors are today part of the European Union, and a global communication allows them to exchange any kind of information across the borders, making it possible to share and juxtapose different cultural readings of broad phenomena such as, for example, like the condition of women, of workers, the conception of family. Still, many of the novels published by those who 
left these countries in the nineties or around 2000 seem to problematize the gap between the experiences of before and after, roughly divided into the East and the West, stressing the weight of the memory and the harshness of the passage, whether it is expressed by physical displacement of the character or by the transformation of the political and social environment in the country of origin.

\section{Between the past and the present}

The presence of socialist regimes and their almost contemporary collapse, often through violent events, unites the recent history of the countries located along the twentieth meridian line. This aspect occurs in a more or less direct and more or less frequent way in the writings of the authors. The violence of a regime that wants to penetrate every aspect of an individual's life entails a disruptive change that traces a vertical and net line between before and after. "Power can do many things, but it cannot stop the time", writes Ingrid Coman $(2010,169)$ in conclusion to her novel Per chi crescono le rose (Who the roses grow for), dedicated to the 1989 Revolution in Romania. The authoress refers to the change that the passage of time brings with it, but also to the constant feeling of 'waiting' that she associates with living under regime as an expression of a form of dependency that the authority creates for its citizens. Moreover, this statement comes shortly before articulating the idea that the 'true' Romanian people were the ones who could finally be seen after the revolution ended (Coman, 169-170). Its wounds were visible and the future unknown, but the transformation that took place was also a chance to define a new identity that would not be 'dictated' anymore.

Among the novels that focus on changes that occurred on the political and social level around that period, the tension between the definition of a people and its own need for a name is often shown as a painful moment. One clear example is given by Croatian Vera Slaven in her novel Cercasi Dedalus disperatamente ([Desperately seeking Dedalus] 1997) regarding Yugoslavian War. In a chapter entitled "La guerra cominciò con la grammatica" ([The war began with grammar] Slaven, 1997, 82-85), some expressive subtleties concerning the social transformation are brought to light: 
The war started just like that, with grammatical blunders, sometimes casual, sometimes intentional. [...] They intended to demonstrate the new indisputable and the most democratic power in the world!

They were intentional when new journalists claimed that Tito was not even a native of our former country, that he was a Russian spy, that he was a Hungarian transvestite. [...] After the Second World War [...] everyone wanted to be the sons of proletarians or sharecroppers, everyone swore that they had no bourgeois aunts, capitalist hoteliers fathers, everyone repudiated kulak uncles or noble relatives. [...]

Now everyone had to [...] be pure Slovenians, pure Serbs, pure Croats, pure Muslims. People changed names and surnames again, these tired people renamed themselves with the new canon of cleanliness, purity, neatness, disinfection (Slaven, 1997, 82).

New definitions for the people are to replace old ones and symbolize the entrance of a new era; still, in both cases, the categories used also reflect different guarantees of safety for those who occupy them. The renaming process is in itself a sign of a revolution taking place (Klemperer, 2013, 77-78), but the new names, far from being felt as a relief by people whom those names should be applied to, seem to be a new origin of anxiety. Most importantly, while declaring itself as 'the most democratic in the world', this new power 'declares' what people should be with no apparent negotiation. What is described, instead, is a reaction by those who not necessarily recognize themselves in these new definitions.

The existence of the printed paper and, by extension, of all the media, leads the manipulative mechanisms of power over language and through language to its maximum expression and, if it cannot harmonize with individual opinions, it makes sure that only homogeneous definitions can circulate (Kutjavina, Saralieva, 2003, 27) along with labels or value judgments with which each individual enters into a relationship. In this context, apparently individual choices about whom to perceive 'similar' to each other, or which group one should identify with, acquire a public character, and are tinged with political connotations, intersecting the precise relationship of the individual with the boundaries that are been imposed from above (Ušakin, 1996, 137). As Gustavo Zagrebelsky (2007, 14-38) teaches, democracy is based on attention to the individual and not the mass, dialogue about the detriment of acquired truths, space given to multiple identities instead of on the imposition of majority identities, and finally quality and variety of the words and public discourse. These few passages from Slaven's novel, and the ones that follow, reveal on the one hand some of 
the ways in which the use of speech can promote a non-democratic power (through the announcement of 'new' truths and the provision of exclusionary labels), and on the other, the sense of disorientation and the spasmodic search for definition by the people, in a context in which security seems to take precedence over identity. It deserves to be noticed, that Slaven traces a parallel between the conditions of the post-war Yugoslavia and the postbreakup of this region, connecting these two different historical moments, the one leading to a dictatorship experience and the other to the formation of democratic states, by similar response from the people, "tired" of redefining themselves according to the power in charge.

While referring to 'grammar', Slaven offers several examples of phenomena which are set in a lexical context. This apparent paradox can be solved if we take into consideration a wider concept of grammar suggested by Noam Chomsky $(1980,222)$, representing the set of rules that hold a society together. The main issue here is that of a shared language whose effectiveness is based on agreement; the substitution of shared formulas can be thus interpreted as a denial of that previous agreement and a declaration of the existence of a society based on new rules:

a new minister declared in a resounding voice: ,And from now on, our television will be called Croatian Radio Television (applause) [...].

An equally new deputy from the region with a Serb majority (or minority) $[\ldots]$ said: „I believe it is more correct to call it Radio Television of Croatia, because not only Croats live in Croatia but also other peoples like Serbians, Italians, Czechs, Hungarians, Russians. [...]

The dispute lasted at least two hours live on television.

In other languages, one cannot even explain where the difference between the two denominations lies, where was the poisonous germ worthy a furious dispute (Slaven, 1997, 82-83).

A war that "started with grammar" uses language as its battlefield, locating it in the public speech. In this episode, we can distinguish two dimensions of the political discourse suggested by Šejgal (2004, 23), the virtual and the real one. To the virtual dimension belongs the genre, the setting of the announcement of the new minister, the formula used, the possibility itself that something can, from now on (!), have a different name. In turn the discussion that follows the announcement, the alternative definitions, and the impact of such discussion on the public are located in the 
real dimension. An element of great importance, here, is the arbitrariness applied to the use of language (Głowiński, 2008), the possibility itself of renaming an entity of public interest such as the National Television, declaring a new idea of community while de-legitimizing the old one. For the second time, Slaven reveals a paradox in suggesting similarities between the pre-Yugoslavia War political condition and what followed immediately after in the same region. It is worth noticing that similar phenomena regarding public speech and political campaign has been observed elsewhere in Central and Eastern European countries (Ponomareva, 2010, 302-303) while, from a formal perspective, the processes that took place led to the foundation of new democratic states; a careful look shows how the verbal dimension in these processes was influenced by formulas from previous, non-democratic regimes.

The need of the power to normalize the very conception of that cultural and linguistic area solicits the internalized image that the individuals who live in that area have (Ušakin, 1996, 137). Thus, Slaven explains: if in the other languages such a dilemma could not technically exist, her particular mother-tongue makes it possible:

The grammar of our language (or, of our languages: Serbian, Croatian, Slovenian, Macedonian, Bosnian [...] what a chaos, what a selfish waste) is difficult, touchy, fussy, offensive, stubborn (and much more, may God save us), sometimes incomprehensible to other peoples.

But if two peoples who have the same origin, the same language, the same destiny (wanting or not) cannot, or rather do not want to understand each other, how can we expect the world to understand us? (Slaven, 1997, 83).

This language that we do not know how to name - by saying Serbo-Croatian we reject the differences, but we exalt them beyond measure by distinguishing the terms - is strongly characterized, personified, endowed with a personality that appears deeply tied to its destiny. But more importantly, the closure in this passage leads us to the starting point of this paragraph, which was the possibility itself to see, and therefore recognize, oneself besides what is suggested from the above. In Coman's novel, a similar question arises after describing the emergence of the Romanian people: "But would the World have eyes to see it?" (Coman, 2010, 169). While postponing the answer to future generations, the authoress seems to be aware of the importance of her writing as a tool to restore a portion of truth. 
In her preface, Coman $(2010,2)$ asks "How much time will have to pass before we catch up with our memories, forget the things that hurt us and heal from our past?" She explains, then, that twenty years of wandering around the world were not enough to give this question an answer, unless the answer is, exactly, to write about it. Remembering the title of a famous essay (Lowenthal, 1985), for this migrant writer the foreign country is the past itself, and she brings it along with her for as long as she carries a memory that can't find words. I would like to suggest, then, that these and other stories might be located at a complex intersection between the past and the present (foreign and local), revealing their peculiar interactions by describing them.

\section{Writing from a distance}

Different historical and cultural paths under the experience of socialist regimes seem to have left similar, often unpredictable signs in individuals born thousands of kilometers from each other. Still, what is important to notice here, is the time and the place where the stories connected to such experiences converge. During our interview, the Romanian-born journalist and writer Anca Martinas points out:

[Living under dictatorship] has enriched me. As a life experience. It gave me a lot, strangely. It allows me to tell. [...] Now, I wouldn't have anything to tell about. [...] A comfortable life is not a life to tell about.

While recalling dramatic moments in Romanian history, Martinas suggests that she can re-evaluate that period today, in the light of the contribution it has given to her creativity. Her first novel published in Italian, Dalla Romania senza amore ([From Romania without love] 2009), has at its core multiple stories of migration, a portrait of Romanian post-1989 society and the memory of a difficult past. The impact of a disaggregated society is shown with special focus on female characters who, despite being strong and able to pick up their lives, are destined to succumb. Their stories, as in many other literary works by Center and Eastern European female migrant writers in Italy (ex.: Țurcanu, 2008; Sorina, 2006), are stories of change, rebellion, attempts of coping with transition from previous 
status - represented by life in the Country of origin, in a non-democratic or disrupted society, sometimes both - to the new one. The change, familiar to anyone who has migrated or who has witnessed a violent transformation of the system in which he lives, is shown in these texts specifically regarding the status of women and their experiences.

Several studies focused on the condition of women in Central and Eastern European countries (Corrin, 1992; Rai, Pilkington, Phizacklea, 1992) suggest that, during the regimes, the image that women had of themselves was attacked by propaganda messages being, ultimately, a source of guilt and unease (Corrin, 1992b, 173-174). An autobiographical example is given, during the interview, by Sarah Zuhra Lukanić, Croatian-born poet and writer. While describing her first approach to writing through sentimental and erotic poems, little understood and little appreciated by those with whom she shared them, she explains that "there was a [concept of] modesty that had nothing to do with religion, that had everything to do with the Party. And I mean that Party".

A literary representation of interference between ideology of the regime and the formation of female gender identity is found in the novel $\mathrm{Il}$ paese dove non si muore mai ([The country where people never die] 2005) by Ornela Vorpsi. A young girl reflects on the taboo surrounding sensuality, while admiring Delacroix's Liberty Leading the People. Therefore, she notes: "Liberty had the power to seduce and to enchant, and it did not seem to have breastfed. Why didn't it happen to a man, to lose his shirt like that? [...] Did sensuality serve the revolution?" (Vorpsi, 2005, 67-68). Filtered through the eyes of the novel character, marked by the prohibitions of the society in which she lives and yet not completely innocent, an important question emerges.

The violence suffered under dictatorship often occurs in the novels of the authors. Among the Albanians, for example, the reference to the imprisonment for political reasons is frequent. The consequences of this experience affect everyone's lives, especially those of their children. Vorpsi writes about it in Il paese dove non si muore mai: "I was the daughter of a political prisoner, so I had to imbue myself with communist education more than others because I was at risk" (Vorpsi, 2005, 19). And again, describing a friend of the protagonist: "[Kristina] lived alone with her mother, her father was in prison. An important difference: he was not a political 
prisoner, he was an ordinary prisoner, meaning not dangerous. He had stolen" (Vorpsi, 2005, 25). In Mari ovunque ([Seas everywhere] 2007) by Elvira Dones, the psychological consequences of political prison are defined as 'hell' that "cannot be told, only suffered", and that "haunts you" even if you survive (Dones, 2007, 84).

This set of examples serves the purpose of reflecting on writing from a distance, given by the physical presence of the author in a different country, by the time passed since the events that are being described and by the use of a different language. We can consider the choice of producing literary work concerning the experience of living in a non-democratic, socialist country either as neutral, belonging to the territory of the writers' creativity, or we can try to connect it with several others and with the testimony of those who have written such works. I would like to follow the latter path, therefore focusing on the impact of memory regarding this specific type of experience.

In a collection edited by Modrzejewski and Sznajderman, the Albanian writer Fatos Lubonja, who spent seventeen years in prison as a political prisoner, tells about his return to the place of his imprisonment. The cells are gone, the buildings have been dismantled. Astonished and disturbed by the fact that one can feel a nostalgic feeling towards the most dramatic moments of one's life, Lubonja suggests the idea of a 'writer's nostalgia'. In fact, he concludes, the attitude towards suffering of those who write is peculiar: the 'writer's nostalgia' reminds of the good and the bad in the same way (Lubonja, 2003, 92-94). Peeter Sauter, Estonian, tries to answer the question "What do you really miss?" with these words: "When we lived in a closed system, there were many unknown things we wanted with a passion so intense it turned into a kind of nostalgia. We dreamed with regret about a lot of things we had never seen, and nostalgia blossomed and flourished from what was missing" (Sauter, 2003, 147).

This yearning for something that one has never possessed, this "consciousness of an elsewhere, awareness of a contrast between past and present, between present and future" (Prete, 1992, 19), also resurfaces in the impressions of the journey that the protagonist of the autobiographical novel by Elvira Mujčić Al di là del Caos ([Beyond the chaos] 2007) accomplishes while traveling, from Italy, back to her native country. When passing Vienna, she notes: "It relaxes me, then it excites me. There is 
a little of my East in it; in the Danube there is a scent of childhood, of things gone, of things never had" (Mujčić, 2007, 70). In Mujčić's novel E se Fuad avesse avuto la dinamite?, Zlatan, the main character, describes the encounter with his fellow countrymen:

People over the age of 25, when the war started, regretted the youth spent in their country [...]. For these people life is divided into a before and an after. The after is a deadlock in which one is stationed, but one does not love it. The before is everything, even more than what it actually was, because if there is one thing that is not honest it is nostalgia: it is cultivated, cared for, and that ends up making you remember things that never existed (Mujčić, 2009, 36).

The Ukrainian writer Jurij Andruchovič hypothesizes that the reason for nostalgia could be "the sense of security, peace, regularity, legal order" (Andruchovič, 2003, 135). As shown from numerous other documents and testimonies collected from inhabitants of former socialist countries, regret is often linked to a peculiar relationship with the centralized and assistentialist state (Banchelli, 2001). The illusion of order and security is generally accompanied by the idea of a purer society, based on ideals, these aspects taken to the extreme in the novel Rigor Artis (2014) by Irina Thurcanu. In this thriller set in 2010's Romania, a serial killer chooses as victims young women with fame ambitions. The cause is not clear until it is discovered that Vlad, this is the name of the character, is an illegitimate son of Ceausescu, seized by the desire to revive the past. He punishes girls who represent values coming from the West, in order to set an example to others. When he meets his first love, he thinks that "she is just an unaware victim of the unhealthy society that surrounds her, of the infected westernism that has ruined a people with an ancient identity" (Țurcanu, 2014, 108). With this tale of grotesque tones, the authoress summarizes a feeling that, according to her, is actually common to many Romanian citizens.

This sense of nostalgia and loss, connected sometimes with a stereotyped East/West opposition, recur differently in several literary texts so far cited. Mujčić's Zlatan states that "Italy was killing my Eastern spirit" (Mujčić, 2007, 48), thus considering the journey back home beneficial. His mother, while blaming him for certain behaviors, says: "You know, it is not nice to lose one's roots like this. You're all Western now" (Mujčić, 2009, 29). Mirsad, a character in Vorpsi's novel, "is sad because the West does 
not understand the truths of the rest of us from the East, the former East. Because truths we have are so different from theirs" (Vorpsi, 2007, 5). The transformation, the encounter between different worlds that we refuse to call 'civilization', but which seem, through the testimony of many voices, to constitute incommunicable spaces, generate mixed feelings. The meeting sometimes seems to sharpen the recognition of an identity defined by the opposition to the West. But the idea of the West itself is marked by a rhetoric belonging to a specific era, to the language of opposition and distance promoted by regimes that were in power before 1989 .

\section{5. 'A meaningful answer'}

By way of conclusion, I would like to make an observation that takes a cue from sociological readings of literature, which suggest, far from an explicit political intent, a power and a role for literary works and the way they can interact with readers' society. In her analysis of the realist novel and its social function, Martha Nussbaum says that the literary work is able to nullify every expedient of self-protection, forcing the reader to "pay attention and react to many things that can be difficult to deal with" (Nussbaum, 2012, 40). The 'power' of literature can be explained by the lowering of defenses, the involvement and the degree of participation that the reader experiences (Nussbaum, 2012, 43). Such a deep 'feeling' of what, in the everyday life, belongs to others' subjectivity, should be a catalyst for understanding otherness and becoming sensitive and empathic towards perspective one would have never shared, perspective based on personal social background. Nussbaum's analysis focuses on the reception while taking into consideration a specific genre whose narratives are deeply connected with social experience. In the novels cited in this article, the other is repeatedly central; through the reading, though, many categories of 'otherness' can be viewed specifically acquiring credibility due to the potential of the literary text. The 'migrant', seen from the outside, emerges as a citizen of an 'other' European country; a poor person is shown in relation to its personal story and the history of its place of origin; a woman is revealed as a person who has high chances of being prevaricated or abused; a strange struggling individual can be connected to a concrete memory baggage and 
to his/her battle to cope with the past and adapt to the present. And although authors are free in creating their plots and defining their characters, the plots and the characters cited seem to suggest a sensitivity towards this face of literature and to express a form of hope regarding its impact.

Lucien Goldmann poses the question whether we should consider the subject of a literary work the individual who wrote it or the social group to which the individual belongs to (Goldmann, 1981, 211-230). He starts from the hypothesis that every human behavior, and so writing, constitutes an attempt to "give a meaningful answer to a specific situation and for this reason it tends to create a balance between the subject of the action and the object to which the action refers, the surrounding world" (Goldmann, 1981, 211). We might take into consideration the idea that this meaningful answer is not necessarily provided by the words written as much as by the ongoing search for words, the possibility itself of writing. It is the act of writing that codifies a new relationship with the environment. This search for balance is at the origin of a transformation cycle, as previous actions generate conditions that subsequent actions will tend to overcome. Thus, any literary work may be regarded as a kind of ambivalent action whose object is the world. If the human being is someone "that cannot see a situation without changing it, because his gaze freezes, destroys or sculpts [...] changes the object" (Sartre, 2009, 14), we might consider the gaze itself, turned into words in the above-mentioned literary works, as a form of action. Its aim is to make the experiences readable, both for the reader and the writer and therefore to counter those experiences that deprive of words.

\section{References}

Andruchovič, J. (2003). Come romanzare l'universo. In: Nostalgia. Saggi sul rimpianto del comunismo. Ed. F. Modrzejewski, M. Sznajderman, Milan: Mondadori, pp. $130-141$.

Banchelli, E. (ed.) (2006). Taste the East. Linguaggi e forme dell' Ostalgie. Bergamo: Bergamo U.P.

Belozorovich, A. (2019). Dal ventesimo meridiano. Migrazione, violenza e scrittura femminile tra Est e Ovest europeo. Roma: Lithos.

Bodrožić, M. (2001). Europa Środkowa, wirtualna tęsknota. "Kafka. Kwartalnik Środkowoeuropejski" nr 2, p. 56. 
Brubaker, R. (1998). I nazionalismi nell'Europa contemporanea. Rome: Editori Riuniti.

Chomsky, N. (1980). Rules and representation. New York: Columbia University Press. Coman, I. (2010). Per chi crescono le rose. Milan: Uroboros.

Cornis-Pope, M., Neubauer, J. (2002). Towards a History of the Literary Cultures in East-Central Europe: Theoretical Reflections. "American Council of Learned Societies Occasional Paper" no. 52.

Corrin, C. (ed.) (1992a). Superwomen and the Double Burden. Women's Experience of Change in Central and Eastern Europe and the Former Soviet Union. London: Scarlet Press.

Corrin, C. (1992b). Gendered identities. Women's experience of change in Hungary. In: Women in the Face of Change. The Soviet Union, Eastern Europe and China. Ed. S. Rai, H. Pilkington, A. Phizacklea, London-New York: Routledge, pp. 167-185. Dones, E. (2007). Mari ovunque. Novara: Interlinea.

Garzaniti, M. (2007). Slavia latina e Slavia ortodossa. Per un'interpretazione della civiltà slava nell'Europa medievale. "Studi Slavistici" no. 4, pp. 29-64.

Garzaniti, M. (2013). Gli slavi. Storia, culture e lingue dalle origini ai nostri giorni. Rome: Carocci.

Glissant, E. (1998). Poetica del diverso. Rome: Meltemi.

Głowiński, M. (2007). Tre saggi su nowomowa e linguaggio del potere. "Pl.it, rassegna italiana di argomenti polacchi". Rome: Lithos, pp. 174-213.

Goldmann, L. (1981). Per una sociologia del romanzo. Una ricerca esemplare sui rapporti tra letteratura e società. Milan: Bompiani.

Górska, U. (2011). Central Europe as an Artistic Category: a Neurosis and Sensitivity. "Porównania" nr 8, pp. 43-59.

Graciotti, S. (1992). La cultura slava. In: Lo spazio letterario del Medioevo 1. Il Medioevo latino, I. La produzione del testo. Ed. G. Cavallo, C. Leonardi, E. Menesto. Rome: Salerno Editrice, pp. 245-267.

Graciotti, S. (1998-1999). Le due Slavie: problemi di terminologia e problemi di idee. "Ricerche slavistiche" XLV-XLVI, pp. 5-84.

Graciotti, S. (2006). Slavia orientale e Slavia occidentale. Contenziosi ideologici e culture letterarie. In: Lo spazio letterario del Medioevo 3. Le culture circostanti. III. Le culture slave. Ed. M. Capaldo. Rome: Salerno Editrice, pp. 75-144.

Huntington, S.P. (1993). The Clash of Civilizations? "Foreign Affairs" 72/3, pp. 22-49. Kąkolewski, I., Olendzki, Z. (1993). The twentieth meridian zone: myth or reality On Marian Malowist's studies on Central-East European history. "Europa. Revue européenne d'Histoire - European review of History" no. 0, pp. 57-72.

Kirshenko, M. (2001). East-Central Europe as a Civilization. Phenomenal and Geopolitical Reality. In: I due polmoni dell'Europa. Est e Ovest alla prova di integrazione. Ed. A. Morganti, A. Piras. Rimini: Il cerchio, pp. 107-110.

Kiš, D. (1987). Variations on the Theme of Central Europe. "Cross Currents. A Yearbook of Central European Culture" no. 6, pp. 1-14.

Klemperer, V. (2013). The Language of The Third Reich. London: Blumsbury. 
Kłoczowski, J. (2009). Introduzione. In: East-Central Europe in European History. Ed. J. Kłoczowski, H. Łaszkiewicz, Lublin: Institute of East-Central Europe.

Kovačević, D. (2007). L'orecchino di Zora. San Giovanni in Persiceto: Eks\&Tra.

Kutjavina, E.E., Saralieva, S.Ch. (2003). Jazyk i vlast': Vlast'i pravo. "Vestnik Nižegorodskogo Universiteta Imeni N.I. Lobačevskogo. Serija Pravo" no. 7, pp. 124-130.

Lowenthal, D. (1985). The Past is a Foreign Country. Cambridge: Cambridge University Press.

Lubonja, F. (2003). Nostalgia e dolore. In: Nostalgia. Saggi sul rimpianto del comunismo. Ed. F. Modrzejewski, M. Sznajderman. Milan: Mondadori, pp. 91-95.

Marinelli, L. (2008). Fra Oriente europeo e Occidente slavo. Russia e Polonia. Rome: Lithos.

Martinas, A. 2009. Dalla Romania senza amore. Rome: Robin.

Miłosz, C. (1986). Central European Attitudes. "Cross Currents. A Yearbook of Central European Culture" no. 5, 2, pp. 101-118.

Modrzejewski, F., Sznajderman, M. (ed.) (2003). Nostalgia. Saggi sul rimpianto del comunismo. Milan: Mondadori.

Moracci, G., Alberti, A. (ed.) (2013). Linee di confine. Separazioni e processi di integrazione nello spazio culturale slavo. Firenze: Firenze University Press.

Mujčić, E. (2007). Al di là del caos. Cosa rimane dopo Srebrenica. Rome: Infinito.

Mujčić, E. (2009). E se Fuad avesse avuto la dinamite? Rome: Infinito.

Mujčić, E. (2012). La lingua di Ana: chi sei quando perdi radici e parole? Rome: Infinito.

Neubauer, J. (2003). What's in a name? Mitteleuropa, Central Europe, Eastern Europe, East-Central Europe. "Kakanien Rivisited" no. 7/5.

Nussbaum, M.C. (2012). Giustizia poetica: immaginazione letteraria e vita civile. Milan: Mimesis.

Picchio, R. (1991). Letteratura della Slavia Ortodossa. Bari: Dedalo.

Ponomareva, O. (2010). 'Ucraina per la gente': Le manipolazioni linguistiche negli slogan elettorali. "Europa Orientalis" no. 29, pp. 291-303.

Prete, A. (1992). Nostalgia. Storia di un sentimento. Milan: Raffaello Cortina.

Rai, S., Pilkington, H., Phizacklea, A. (ed.) (1992). Women in the Face of Change. The Soviet Union, Eastern Europe and China. London-New York: Routledge.

Sartre, J.-P. (2009). Che cos'è la letteratura? Lo scrittore e i suoi lettori secondo il padre dell'esistenzialismo. Milano: Il Saggiatore.

Šejgal, E.I. (2004). Semiotika političeskogo diskursa: monografija. Volgograd: Peremena.

Sauter, P. (2003). Lenin vive ancora? In: Nostalgia. Saggi sul rimpianto del comunismo. Ed. F. Modrzejewski, M. Sznajderman. Milan: Mondadori, pp. 142-152.

Slaven, V. (1997). Cercasi Dedalus disperatamente. Pescara: Tracce.

Sorina, M. (2006). Voglio un marito italiano. Dall'est per amore? Vicenza: Il punto d'incontro.

Stokes, G. (1997). Three Eras of Political Change in Eastern Europe. New YorkOxford: Oxford University Press. 
Szücs, J. (1996). Disegno delle tre regioni storiche d'Europa. Soveria Mannelli: Rubbettino.

Todorova, N.M. (1996). Hierarchies of Eastern Europe: East-Central Europe versus the Balkans. "East-European Studies" occasional paper no. 46.

Ţurcanu, I. (2008). Alia, su un sentiero diverso. Turin: Seneca Edizioni.

Ţurcanu, I. (2010). La frivolezza del cristallo liquido. Rome: Absolutely Free.

Ţurcanu, I. (2014). Rigor artis. Rome: Absolutely Free.

Ušakin, S.A. (1996). Posle modernizma: jazyk vlasti ili vlast' jazyka. "Obščestvennye nauki i sovremennost"' no. 5, pp. 130-141.

Vitale, A. (2001). La 'Slavia ortodossa' e la politica internazionale. Questioni di geopolitica e di geocultura. In: I due polmoni dell'Europa. Est e Ovest alla prova di integrazione. Ed. A. Morganti, A. Piras. Rimini: Il cerchio, pp. 89-106.

Vorpsi, O. (2005). Il paese dove non si muore mai. Turin: Einaudi.

Vorpsi, O. (2007). La mano che non mordi. Turin: Einaudi.

Wolff, L. (1994). Inventing Eastern Europe. The Map of Civilization on the Mind of the Enlightenment. Stanford: Stanford University Press.

Zagrebelsky, G. (2007). Imparare democrazia. Turin: Einaudi.

Ziffer, G. (2007). Aspetti storico-linguistici della cristianizzazione del mondo slavo. In: Gli studi slavistici in Italia oggi. Ed. R. De Giorgi, S. Garzonio, G. Ziffer. Udine: Forum, pp. 41-50. 